\title{
Uji Kadar Anti-HBs pada Balita Penerima Imunisasi Dasar
}

\section{Test Of Anti-HBs Level on Under-Five Children Received Basic Immunization}

\author{
Lucia Sincu Gunawan* dan Ratna Herawati \\ Fakultas Ilmu Kesehatan Universitas Setia Budi \\ *Corresponding author: sincugunawan@gmail.com
}

\begin{abstract}
ABSTRAK
Hepatitis B merupakan masalah kesehatan global, diperkirakan sekitar 2 miliar penduduk dunia pernah terpapar virus Hepatitis B (HBV). Angka prevalensi infeksi HBV di Asia Pasifik cukup tinggi, yaitu melebihi $8 \%$ dan penularannya umumnya terjadi secara vertikal (pada periode perinatal) dan horizontal (pada masa anak-anak) sehingga risiko menjadi infeksi yang kronis menjadi cukup besar. Pencegahan dengan vaksinasi merupakan strategi terpenting untuk menurunkan risiko infeksi virus hepatitis B kronis dan komplikasinya. Antibodi anti-HBs berdasarkan pengukuran antibodi Anti HBs secara in vitro dengan menggunakan test diagnostik laboratorium secara imunologis. Titer antibodi hepatitis B ini dikatakan protektif bila titernya lebih dari $10 \mathrm{mIU} / \mathrm{ml}$.

Pada penelitian ini dilakukan pemeriksaan kadar anti-HBs secara semi kuantitatif pada anak balita penerima imunisasi dasar yang lengkap, menggunakan rapid test dan dilakukan pengenceran pada serum dengan serokonversi positif.

Diperoleh serum dari 23 balita yang memenuhi syarat dan dari hasil pemeriksaan anti-HBs didapatkan 20 anak (87\%) dengan serokonversi positif dan 3 anak (13\%) dengan serokonversi negatif. Untuk serum dengan serokonversi positif, maka selanjutnya dilakukan pemeriksaan serum dengan pengenceran, hasilnya 4 sampel (20\%) negatif pada pengenceran 1:2, 3 sampel (15\%) positif sampai pengenceran 1:2 saja, 5 sampel (25\%) positif sampai pada pengenceran 1:4, 4 sampel (20\%) positif pada pengenceran 1:6, 2 sampel(10\%) positif pada pengenceran 1:8 dan 2 sampel (10\%) tetap positif padapengenceran 1:10.
\end{abstract}

Kata kunci: Imunisasi Hepatitis B, Anti-HBs

\section{ABSTRACT}

Hepatitis B is a global health problem, estimated to be around 2 billion of the world's population has been exposed to $H B V$. The prevalence rate of $H B V$ infection in Asia Pacific is high enough that exceeds $8 \%$ and its transmission generally occurs vertically (in the perinatal period) and horizontally (in childhood) so the risk of becoming a chronic infection becomes quite large. Prevention with vaccination is the most important strategy to reduce the risk of chronic hepatitis $B$ virus infection and its complications. Anti-HBs based on anti-HBs antibody measurements in vitro by using immunological laboratory diagnostic tests. Hepatitis B antibody titre is said to be protective when anti-HBs antibody titer is more than $10 \mathrm{mIU} / \mathrm{ml}$.

In this study, semi-quantitative anti-HBs levels were assessed for completed immunization under-five-years children, using rapid test and then serum dilution for positifseroconversion results.

The results of anti HBs from 23 eligible serum were, 20 children (87\%) with positif seroconversion and 3 children (13\%) with negatif seroconversion. For serum with positif seroconversion, serum examination was performed with dilution, obtained $4(20 \%)$ negatif samples at 1:2 dilution, 3 positifsamples (15\%) until 1:2 dilution alone, 5 samples (25\%) positif until 1:4 dilution, 4 samples (20\%) positif at 1:6 dilution, 2 samples (10\%) positif at 1:8 dilution and 2 samples (10\%) remained positif at 1:10 dilution.

Keywords: Hepatitis B Immunization, Anti-HBs

\section{PENDAHULUAN}

Hepatitis B adalah infeksi hati yang disebabkan oleh virus hepatitis B (HBV). Virus hepatitis B adalah virus DNA, suatu prototip virus yang termasuk keluarga Hepadnaviridae yang dapat menyebabkan peradangan hati akut atau kronis, yang pada sebagian kecil kasus dapat berlanjut menjadi sirosis hati atau kanker hati. (Anonim, 2016).

Hepatitis B merupakan masalah kesehatan 
global, diperkirakan sekitar 2 miliar penduduk dunia pernah terpapar HBV. Angka prevalensi infeksi HBV di Asia Pasifik cukup tinggi yaitu melebihi $8 \%$ dan penularannya umumnya terjadi secara vertikal (pada periode perinatal) dan horizontal (pada masa anak-anak) sehingga risiko menjadi infeksi yang kronis menjadi cukup besar. Pada saat ini sekitar 1 juta kematian per tahun akibat penyakit hati berhubungan dengan HBV. Sirosis hati, gagal hati, atau kanker hati dapat terjadi pada 15 - $40 \%$ penderita dengan infeksi hepatitis B kronis. Di negara berkembang, orang dewasa sangat berisiko tinggi untuk terkena hepatitis B, terlebih di negara miskin. Hepatitis B dengan endemis tinggi, cukup banyak ditemukan pada anak-anak. Karena tingginya morbiditas dan mortalitas yang diakibatkan hepatitis B, penyakit ini sangat mengancam di dunia. (Zain LH, 2006) Indonesia saat ini masih menjadi negara dengan hepatitis terbesar nomor dua di antara negara South-East Asia Regional Office (SEARO). SEARO terdiri dari 11 negara yaitu Bangladesh, Bhutan, Korea Utara, India, Maladewa, Myanmar, Nepal, Sri Lanka, Thailand, Timor-Leste dan Indonesia. Berdasarkan penelitian Kementerian Kesehatan, 50 persen penderita hepatitis B dan $\mathrm{C}$ di Indonesia diperkirakan akan berkembang menjadi gangguan hati kronis. Sedangkan 10 persennya berpotensi berkembang menjadi kanker hati. Berdasarkan data lapangan Kemenkes pada 2007-2012 penderita hepatitis B melebihi 31 persen dari kasus hepatitis secara umum. (Sufa IG, 2013)

Di dalam menggambarkan situasi Hepatitis di Indonesia, diambil sumber data dari Pusdatin Kemenkes dan hasil Riskesdas Badan Litbangkes yang dilakukan analisis sederhana secara diskriptif. Menurut hasil Riskesdas tahun 2013 jumlah orang yang didiagnosis hepatitis oleh tenaga kesehatan berdasarkan gejala gejala yang ada, menunjukkan peningkatan 2 kali lipat apabila dibandingkan dengan tahun 2007. Hal ini dapat memberikan petunjuk awal ke kita tentang upaya pengendalian di masa lalu, peningkatan akses, potensial masalah dimasa yang akan datang apabila tidak segera dilakukan upaya upaya yang serius. Apabila kondisi di atas disandingkan dengan upaya imunisasi yang telah dilakukan sejak tahun 2000 hingga tahun 2013, terlihat keadaan yang cukup kontradiktif, yaitu sejak tahun 2007 hingga tahun 2013 cakupan imunisasi Hepatitis B cukup signifikan peningkatannya, bahkan di tahun 2012 dan 2013 cakupan immunisasi melebihi target yang ditentukan. Namun disisi lain prevalensi Hepatitis dari tahun 2007 ke tahun 2013 juga meningkat di setiap kelompok usia. (Anonim, 2015)

Berbeda dengan data di atas, disebutkan oleh Anna LK bahwa proporsi penduduk yang terinfeksi virus hepatitis B dari tahun 2007 ke 2013 menurun. Kondisi itu dinilai sebagai wujud keberhasilan program imunisasi hepatitis B yang dimulai nasional sejak 1997. Riset Kesehatan Dasar (Riskesdas) 2013 juga menunjukkan, pada kelompok umur 19 tahun ke bawah, proporsi Anti-HBc (Anti-Hepatitis B Core Antigen) terhadap Anti-HBs (Hepatitis $B$ Surface Antibody) rendah. Artinya, di kelompok umur itu, antibodi terhadap hepatitis B lebih banyak diperoleh dari vaksinasi daripada karena infeksi secara langsung. Meski begitu, upaya pencegahan dengan imunisasi masih perlu ditingkatkan. (Anna LK, 2015)

Tiga strategi utama pencegahan yaitu modifikasi pola hidup untuk pencegahan penularan atau transmisi, imunisasi aktif dan imunisasi pasif. Perubahan perilaku seksual dan skrining terhadap produk darah untuk transfusi dapat mengurangi risiko terinfeksi hepatitis B. Pencegahan dengan vaksinasi merupakan strategi terpenting untuk menurunkan risiko infeksi virus hepatitis B kronis dan komplikasinya. (Anna LK,2015) Generasi pertama adalah plasma derived vaccine yang tidak aktif yang diperkenalkan pada tahun 
1982. Generasi kedua merupakan rekombinan DNA yang dipergunakan secara luas tahun 1986. Kedua vaksin tersebut cukup aman dan efektif dalam mencegah infeksi hepatitis B. Pada tahun 1991, World Health Organization (WHO) telah merekomendasikan vaksinasi hepatitis B untuk seluruh negara. Tahun 2002, 154 negara telah melakukan vaksinasi hepatitis B pada seluruh bayi baru lahir. (Anna LK, 2015) Meskipun upaya imunisasi telah dijalankan sejak tahun 1997 akan tetapi prevalensi hepatitis B masih tetap tinggi. Penelitian menunjukkan bahwa beberapa faktor yang kemungkinan menyebabkan gagalnya suatu imunisasi antara lain adanya mutasi virus. Mutasi ini mungkin akibat vaksin yang dibuat bukan berdasarkan galur virus lokal sehingga antibodi yang terbentuk tidak mampu membunuh virus hepatitis B yang ada. Oleh karena itu perlu desain vaksin hepatitis B yang tepat dan optimum untuk Indonesia. Selain itu adanya nonresponder atau orang yang telah divaksinasi tetapi tidak terbentuk antibody, merupakan penyebab utama ketidakberhasilan suatu vaksinasi. Hal ini dapat terjadi karena vaksin kurang imunogenik atau vaksin mudah mengalami netralisasi. (Astuti HP, 2014) Disamping itu ada kemungkinan yang tak kalah penting adanya kasus vaksin palsu, tidak dapat kita kesampingkan sebagai penyebab gagalnya suatu vaksinasi, seperti berita heboh yang kita dengar tahun kemarin.

Anti-HBs adalah pertanda adanya antibodi terhadap virus hepatitis B pada seseorang. Antibodi yang terbentuk bisa disebabkan infeksi virus hepatitis $B$, atau berasal dari vaksinasi hepatitis B. (Anna LK, 2015) Anti HBs adalah penanda serologi untuk mengetahui system imunitas tubuh terhadap vaksinasi ataupun akibat infeksi. Anti HBs juga digunakan monitor masa penyembuhan dari infeksi Hepatitis B. adanya anti HBs setelah infeksi akut HBV dan hilangnya HbSAg menunjukkan kesembuhan dari penyakit. (Jatmiko dan Aisyah, 2015)
Antibodi anti-HBs diperiksa berdasarkan pengukuran antibodi anti-HBs secara in vitro dengan menggunakan test diagnostik laboratorium secara imunologis. Titer antibodi hepatitis B dikatakan protektif bila titer antibodi anti-HBs $>10 \mathrm{mIU} / \mathrm{ml}$. Ini merupakan parameter yang dapat digunakan sebagai penanda keberhasilan dari sebuah program vaksinasi hepatitis B yang dilakukan satu paket yakni tiga kali pada bulan ke-0, bulan ke-1 dan bulan ke-6. (Setiawan PB, 2006) Seyogyanya pemeriksaan kadar antibodi anti-HBs ini dikerjakan guna melihat keberhasilan program vaksinasi, tapi pada kenyataan di lapangan sangatlah jarang dilakukan. Cakupan imunisasi yang berhasil sering dinilai dari kunjungan atau jumlah bayi yang menerima vaksin. Fakta tetap tingginya angka kejadian infeksi hepatitis B ini menjadi latar belakang penulis melakukan penelitian tentang kadar anti-HBs pada balita penerima imunisasi dasar, dan diharapkan di kemudian hari anti-HBs dapat digunakan sebagai parameter yang lebih efektif dalam menilai keberhasilan program imunisasi hepatitis B dibandingkan jika hanya menggunakan data jumlah kunjungan. Berdasar latar belakang masalah di atas, maka dalam penelitian ini diuji kadar anti HBs pada balita penerima imunisasi dasar.

\section{METODE PENELITIAN}

\section{Lokasi Penelitian}

Tempat pengambilan sampel darah dilakukan di praktek mandiri peneliti, sedangkan pemeriksaan sampel darah dilakukan di Laboratorium Universitas Setia Budi Surakarta.

\section{Subyek Penelitian \\ Populasi}

Populasi dalam penelitian ini adalah seluruh anak bawah usia lima tahun (balita) di Kota Surakarta pada praktek mandiri dokter. 


\section{Sampel}

Sampel penelitian adalah anak balita yang telah mendapatkan imunisasi dasar hepatitis B lengkap (3 kali), yakni sebanyak 23 orang. Teknik pengambilan sampel adalah incidental

\section{Metode Pemeriksaan}

Rapid HBs-Ab Test (semiquantitative test)

\section{Prinsip Pemeriksaan}

Adanya antibodi spesifik terhadap HBV di dalam sampel akan bereaksi dengan antigen HBV yang melapisi membran uji dan yang kemudian akan bermigrasi secara kromatografi di sepanjang membran dan membentuk kompleks antigen-antibodi yang ditunjukkan dengan terbentuknya garis warna pada membran uji.

\section{Alat dan Bahan \\ Alat}
a. Tabung vakum non antikoagulan
b. Jarum disposable
c. Jarum "kupu-kupu" disposable
d. Holder
e. Tourniquet
f. Alkohol Swab
g. Kasa kering
h. Centrifuge
I. Tabung serologis

\section{Bahan Sampel Pemeriksaan}

Serum $(\mathrm{NaCl}$ fisiologis sebagai pengencer)

\section{Reagen}

Chemtrue Rapid HBsAb dan One Step Hepatitis Surface Antibody Test Strip

\section{Tindakan Pencegahan}

a. Untuk diagnosa in vitro yang profesional, tidak digunakan rapid test yang telah melewati tanggal kadaluarsa.

b. Tidak makan, minum atau merokok di area spesimen dan ketika kit sedang digunakan. c. Perlakuan bahwa semua spesimen adalah bahan infeksius. Amati tindakan pencegahan terhadap resiko bahaya mikrobiologi seluruh pengujian dan mengikuti prosedur standar untuk pembuangan spesimen.

d. Menggunakan pakaian pelindung jas laboratorium, sarung tangan disposable ketika spesimen sedang diperiksa.

e. Kelembaban dan suhu akan mempengaruhi hasil.

Tes strip dapat disimpan pada suhu kamar atau pendingin $\left(2-30^{\circ} \mathrm{C}\right)$. Tes strip tetap stabil sampai tanggal kadaluarsa yang tertera pada kemasan. Tes strip harus tetap dalam kantong tertutup sampai digunakan. Tidak diperkenankan dibekukan.

f. Pengumpulan dan Persiapan Spesimen

1. Memisahkan serum dari endapan sel-sel darah sesegera mungkin untuk menghindari hemolisis. Hanya spesimen yang jernih dan tidak hemolisis yang dapat digunakan.

2. Pengujian harus dilakukan segera setelah spesimen dikumpulkan. Tidak meninggalkan spesimen di suhu ruangan untuk memperpanjang periode. Spesimen harus disimpan pada suhu $2-8^{\circ} \mathrm{C}$ agar dapat bertahan 3 hari. Untuk masa penyimpanan yang lebih lama, spesimen harus disimpan dibawah $-20^{\circ} \mathrm{C}$.

3. Membawa spesimen ke suhu ruangan lebih dahulu untuk pengujian. Bekuan spesimen harus sepenuhnya dicairkan dan dicampur dengan baik untuk pengujian. Spesimen tidak boleh dibekukan dan dicairkan ulang.

\section{Prosedur Pemeriksaan}

\section{Prosedur Pengambilan Darah Vena}

a. Pasanglah jarum pada holder, pastikan terpasang erat.

b. Lakukan pendekatan pasien dengan tenang agar pasien nyaman.

c. Identifikasi pasien dengan benar sesuai data pada lembar permintaan pada orang 
tua/wali.

d. Minta pasien meluruskan lengannya, pilih lengan yang banyak melakukan aktifitas.

e. Mintalah pasien untuk mengepalkan tangan.

f. Pasang tali pembendung (turniket) kira-kira $5 \mathrm{~cm}$ di atas lipat siku.

g. Pilih bagian vena mediana cubiti atau vena cephalic. Lakukan perabaan (palpasi) untuk memastikan posisi vena, vena teraba seperti sebuah pipa kecil, elastis dan memiliki dinding tebal. Bersihkan kulit pada bagian yang akan diambil dengan alkohol swab $70 \%$ dan biarkan kering.

h. Tusuk bagian vena dengan posisi lubang jarum menghadap ke atas. Masukkan tabung ke dalam holder dan dorong sehingga jarum bagian posterior tertancap pada tabung, maka darah akan mengalir masuk ke dalam tabung. Tunggu sampai darah secukupnya.

i. Lepas turniket dan minta pasien membuka kepalan tangannya. Letakkan kasa kering di tempat suntikan lalu segera lepaskan/tarik jarum. Tekan kapas beberapa saat lalu pasang plester.

\section{Prosedur Pembuatan Serum}

a. Biarkan darah membeku sempurna dalam tabung vakum kurang lebih 45 menit.

b. Tabung di-sentrifuge selama 10 menit pada kecepatan $3000 \mathrm{rpm}$.

c. Pisahkan lapisan jernih serum dari endapan sel-sel darah secara hati-hati dengan pipet pasteur.

d. Tempatkan serum di dalam tabung serum dan beri label mewakili identitas.

e. Perhatikan suhu dan waktu dalam penyimpanan serum bila tidak segera

\section{Prosedur Pemeriksaan Anti-HBs dengan rapid test}

a. Pastikan tes strip dan spesimen serum agar sama dengan suhu kamar $\left(15-30^{\circ} \mathrm{C}\right)$ sebelum pemeriksaan. b. Bawa kemasan pada suhu kamar sebelum dibuka. Keluarkan tes strip dari kemasan dan segera gunakan. Hasil terbaik akan diperoleh bila kinerja dilakukan dalam satu jam.

c. Dengan panah menunjuk ke arah spesimen serum, celupkan tes strip secara vertikal pada serum setidaknya selama 10-15 detik. Jangan melewati garis batas maksimum (MAX) pada tes strip saat mencelupkan tes strip.

d. Tempatkan tes strip pada permukaan datar yang tidak dapat menyerap, mulai hitung waktu dan tunggu sampai garis merah muncul. Hasilnya harus dibaca pada 15 menit.

e. Interpretasi hasil :

1) Positif : ditandai dengan tampaknya 2 garis merah. Satu garis pada area kontrol dan satu pada area uji. Intensitas warna yang terbentuk tergantung kadar anti-HBs dalam serum.

2) Negatif : satu garis merah pada area kontrol dan tidak tampak adanya garis merah ataupun merah muda pada area uji.

3) Invalid : jika tidak tampak garis merah pada area kontrol. Hasil invalid sering timbul akibat kurangnya volume spesimen atau salah prosedur. Lakukan pemeriksaan ulang dengan tes strip baru dan jika masih sama hasil invalid yang didapatkan, gunakan tes strip jenis lainnya.

f. Catatan : konsentrasi antibodi HBs yang rendah akan muncul dalam garis lemah pada area tes (T) setelah melampaui jangka waktu, oleh karena itu jangan membaca hasil setelah lebih dari 20 menit.

g. Hasil pemeriksaan yang positif, akan dilanjutkan dengan pengenceran. Pengenceran 1:2 artinya satu bagian serum ditambahkan satu bagian $\mathrm{NaCl}$ fisiologis, kemudian dilakukan pemeriksaan ulang dengan rapid test dan seterusnya. 


\section{HASIL DAN PEMBAHASAN}

Pada awal rencana penelitian, direncanakan subyek penelitian adalah balita yang memeriksakan diri di Bagian Kesehatan Ibu dan Anak Puskesmas Banyuanyar Kota Surakarta, sehingga penulis melakukan koordinasi dan pengurusan ijin di tingkat kota. Dikarenakan tidak diperoleh ijin, maka penulis menggunakan subyek penelitian balita di praktek mandiri penulis. Karena keterbatasan populasi, maka hanya didapatkan sampel penelitian sebanyak 23 anak, yakni balita yang telah melakukan imunisasi dasar lengkap dan bersedia untuk mengikuti pemeriksaan.

Alur kegiatan dimulai dengan adanya pendaftaran, pengisian kuesioner yang dipandu oleh penulis, penjelasan tujuan kegiatan, pengisian informed consent oleh orang tua atau wali, pengambilan darah, pemberian gimmick, dan pemeriksaan sampel di laboratorium. Setelah hasil pemeriksaan laboratorium dikeluarkan, maka disampaikan pada orang tua wali saat kunjungan berikutnya dan diberikan nasehat, khususnya untuk balita dengan antiHBs yang serokonversi negatif. Pada balita dengan hasil serokonversi negatif diberikan imunisasi booster ulang satu kali dan akan kembali dicek darahnya satu bulan setelah tanggal imunisasi ulang tersebut, namun kali ini bekerjasama dengan laboratorium swasta.
Berdasarkan jenis kelamin, sebagaimana terlihat pada tabel 4.1, dari 23 balita, didapatkan anak laki-laki sebanyak $16(70 \%)$ dan anak perempuan sebanyak $7(30 \%)$, dengan status gizi baik 19 anak (83\%), gizi kurang 3 anak (13\%) dan 1 anak (4\%) dengan gizi lebih (Tabel 4.2). Dan juga dari tabel 4.3 terlihat, 15 anak (65\%) dengan usia di bawah tiga tahun (batita) dan 8 anak balita (35\%) di atas usia 3 tahun. Mereka mendapatkan vaksinasi di macammacam tempat seperti di puskesmas, posyandu, bidan, klinik maupun rumah sakit.

Pada penelitian sebelumnya, Fauzah menyatakan bahwa kondisi yang mempengaruhi keberhasilan tanggap kebal atau respon imun setelah vaksinasi hepatitis B pada bayi dengan berat lahir rendah adalah status pejamu seperti umur, jenis kelamin, kenaikan berat badan 6 bulan pertama kehidupan. Ada perbedaan jenis kelamin pada respon imun, perempuan mempunyai respon imun yang lebih baik daripada laki-laki (Yugata HH, 2015)

Pada penelitian yang dilakukan oleh Gad dan Shah (2007) menunjukkan hasil tingkat respon imun protektif setelah 3 dosis vaksin meningkat dengan respon kenaikan berat badan 6 bulan pertama kehidupan. Depkes (2009) menyatakan satu seri vaksinasi yang tepat dapat membentuk respon imun yang cukup $95 \%$ orang sehat. Pada umumnya respon vaksin

Tabel 4.1. Hasil Uji Anti-HBs Berdasar Jenis Kelamin

\begin{tabular}{lccc}
\hline Jenis Kelamin & \multicolumn{2}{c}{ Anti HBs } & Total \\
& Negatif & Positif & \\
\hline Perempuan & 0 & 6 & 6 \\
Laki-laki & 3 & 14 & 17 \\
\hline Total & 3 & 20 & 23 \\
\hline
\end{tabular}

Data Primer Maret 2017

Tabel 4.2.Hasil Uji Anti-HBs Berdasar Status Gizi

\begin{tabular}{lccc}
\hline Status Gizi & \multicolumn{2}{c}{ Anti-HBs } & Total \\
& Negatif & Positif & \\
\hline Kurang & 0 & 3 & 3 \\
Baik & 3 & 16 & 19 \\
Lebih & 0 & 1 & 1 \\
\hline Total & 3 & 20 & 23 \\
\hline
\end{tabular}

Data Primer Maret 2017 
Tabel 4.3. Hasil Uji Anti-HBs Berdasar Kelompok Umur

\begin{tabular}{lccc}
\hline Umur & \multicolumn{2}{c}{ Anti HBs } & Total \\
& Negatif & Positif & \\
\hline$<3$ tahun & 0 & 12 & 12 \\
$\geq 3$ tahun & 3 & 8 & 11 \\
\hline Total & 3 & 20 & 23 \\
\hline
\end{tabular}

Data Primer Maret 2017

Tabel 4.4. Hasil Uji Anti-HBs Berdasar Jenis Kelamin, Status Gizi dan Umur

\begin{tabular}{llcc}
\hline & & \multicolumn{2}{c}{ Anti-HBs } \\
& & Positif & Negatif \\
\hline \multirow{4}{*}{ Jenis Kelamin } & Laki-laki & 13 & 3 \\
& Perempuan & 7 & 0 \\
\multirow{4}{*}{ Umur } & Baik/Lebih & 17 & 3 \\
& Kurang & 3 & 0 \\
& $<3$ tahun & 15 & 0 \\
& $\geq 3$ tahun & 5 & 3 \\
\hline
\end{tabular}

Data Primer Maret 2017

Tabel 4.5. Hasil Uji Kadar Anti-HBs pada Balita Penerima Imunisasi Dasar

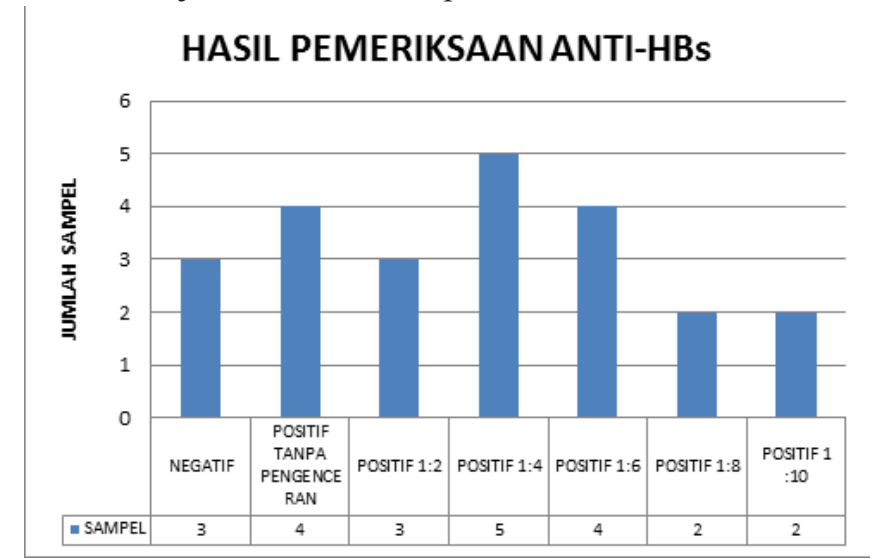

Data Primer Maret 2017

terhadap bayi dan anak yang sehat sangat baik untuk menghasilkan titer antibodi yang tinggi meski dengan dosis yang lebih kecil dibandingkan dewasa. (Yugata HH, 2015)

Pada penelitian yang dilakukan oleh Sampana tahun 2000 menunjukkan perlindungan vaksin hepatitis $\mathrm{B}$ bila disuntikkan pada bayi umur 0-7 hari sebesar $100 \%$, bila disuntikkan pada bayi umur lebih dari 7 hari, tingkat perlindungan sebesar 90,28\%. Pada penelitian yang lain, tingkat seroprotektif (anti HBs $>=10 \mathrm{IU} / \mathrm{L}$ ) pada anak usia 1 tahun adalah $100 \%$ dan pada anak usia 5 tahun adalah $37 \%$, sehingga disimpulkan usia berkorelasi negative dengan titer anti HBs. (Yugata HH, 2015)

Dari hasil pemeriksaan kadar Anti-HBs didapatkan 20 anak (87\%) dengan serokonversi positif dan 3 anak (13\%) dengan serokonversi negatif. Pada pemeriksaan dengan hasil serokonversi negative selanjutnya dilakukan pemeriksaan ulang untuk memastikan validitas hasil pemeriksaan dengan menggunakan rapid test yang sama dan berbeda merk.

Untuk balita dengan serokonversi positif, maka dilakukan pemeriksaan serum dengan pengenceran. Hal ini sesuai dengan metode pemeriksaan semi kuantitatif yang dikerjakan pada penelitian ini. Pemeriksaan dimulai dari pengenceran 1:2 sampai didapat hasil negatif, maka pemeriksaan diakhiri. Dari tabel 4.5 di bawah terlihat hasil pengenceran yang dilakukan pada serum dengan serokonversi positif, yaitu 4 sampel (20\%) negatif pada 
pengenceran 1:2, 3 sampel(15\%) positif sampai pengenceran 1:2 saja, 5 sampel (25\%) positif sampai pada pengenceran 1:4, 4 sampel (20\%) positif pada pengenceran 1:6, 2 sampel(10\%) positif pada pengenceran 1:8 dan 2 sampel (10\%) tetap positif pada pengenceran 1:10.

Dari 23 sampel yang diperiksa kadar antiHBs nya didapatkan 3 sampel (13\%) dengan hasil negatif. Hasil negatif ini sudah dikonfirmasikan dengan pemeriksaan ulang dan penggunaan alat dengan merk lain. Artinya kadar anti- HBs pada ketiga sampel adalah kurang dari $10 \mathrm{mIU} / \mathrm{ml}$. Secara klinis ini bermakna kurangnya daya proteksi anti-HBs terhadap infeksi virus hepatitis B yang mungkin bisa terjadi di kemudian hari pada anak-anak ini. Pada pertemuan berikutnya, disampaikan hasil pemeriksaan kepada orang tua atau wali dan dilakukan motivasi untuk vaksinasi ulang. Setelah vaksinasi yang dilakukan sekali lagi, maka sebulan kemudian dilakukan pemeriksaan ulang di Laboratorium Budi Sehat Surakarta.

Hasil negatif ini berkaitan dengan beberapa faktor, seperti adanya respon imun yang kurang adekuat, usia dan jenis kelamin, penggunaan jenis vaksinasi yang kurang baik daya imunogenitasnya, metode penyuntikan dan halhal yang tidak diketahui secara pasti. Hasil negatif ini akan menimbulkan dampak tidak terlindunginya tubuh anak terhadap infeksi hepatitis B, sedangkan di sisi lain masyarakat sudah puas dan merasa aman karena merasa sudah melengkapi anak dengan imunisasi dasar. Adanya anti-HBs dengan kadar protektif diharapkan dapat mencegah penularan hepatitis B pada anak yang biasanya berujung pada hepatitis B yang kronik. Pembuatan vaksin yang tidak sesuai dengan galur lokal, merupakan suatu tantangan sendiri bagi industri farmasi dalam negeri untuk memproduksinya, sehingga diharapkan nilai proteksi yang lebih tinggi bagi masyarakat. Selain produksi, pengawasan distribusi vaksin pun perlu ditingkatkan, karena penyimpanan yang baik akan menjamin kualitas produk sampai ke konsumen akhir. Adanya berita tentang vaksin palsu, baik produksi dan distribusinya yang tidak terdeteksi sekian tahun, menjadi pertanyaan apakah selama ini anak balita yang mendapat vaksinasi telah terlindungi terhadap virus hepatitis B ini. Seperti kita ketahui, bahwa meskipun insiden hepatitis B menurun dengan imunisasi secara aktif, tetapi kasusnya masih tetap akan menjadi masalah global terlebih dengan komplikasi infeksi kroniknya berupa sirosis dan kanker hati.

Keterbatasan rapid test ini adalah hanya dapat digunakan pada diagnosis in vitro, menggunakan specimen serum ataupun plasma. Tes ini juga tidak dapat mendeteksi kadar anti HBs kurang dari $10 \mathrm{mIU} / \mathrm{ml}$. Karena pemeriksaan ini merupakan pemeriksaan kualitatif, maka hasilnya dari tiap pengenceran adalah berupa estimasi nilai, seperti pada tes pertama didapatkan positif maka dilakukan pengenceran 1:2. Jika hasil yang didapatkan adalah negatif maka rata-rata kadar anti-HBsnya adalah $10-19 \mathrm{mIU} / \mathrm{ml}$. Jika positif bermakna kadar anti-HBs adalah di atas $20 \mathrm{mIU} / \mathrm{ml}$ dan seterusnya. Beberapa referensi menyatakan bahwa batas nilai proteksi anti-HBs adalah $10 \mathrm{mIU} / \mathrm{ml}$, tetapi beberapa laboratorium punya nilai yang lebih tinggi yakni di atas $24 \mathrm{mIU} / \mathrm{ml}$. Hal ini berkaitan dengan jenis alat dan reagen yang berbeda, meski pada penatalaksanaan klinis akan memiliki interpretasi dan tata laksana yang berbeda pula.

Selain itu hal-hal yang dapat mempengaruhi mutu pemeriksaan laboratorium dibagi 2 komponen yaitu ketepatan dan ketelitian. Secara umum, faktor yang dapat mempengaruhi hasil laboratorium dibagi menjadi 3 kategori utama yaitu pra analitik, analitik dan paska analitik. Factor pra analitik dijumpai sebelum spesimen pasien diperiksa. Faktor-faktor ini meliputi ketatausahaan, persiapan pasien, pengumpulan spesimen, dan penanganan spesimen. Faktor analitik terdapat pada proses pengukuran, seperti reagen, peralatan, kontrol 
dan bakuan/standar, metode analitik dan sumber daya manusia/ahli teknologi. Faktor paska analitik terdapat pada proses setelah pengambilan spesimen dan proses pengukuran, meliputi perhitungan, cara penilaian, ketatausahaan dan penanganan informasi. (Riswanto, 2013)

Adanya daya proteksi vaksinasi hepatitis B sebesar 95\% menunjukkan peran penting vaksinasi dalam mencegah terjadinya infeksi. Usaha pencegahan tentu lebih bermakna dan lebih mudah daripada pengobatan dan penatalaksanaan peyakit infeksi ini. Apalagi dengan stigma yang timbul pada masyarakat serta dampak psikologis penderita hepatitis B, dimana banyak pembatasan profesi dan bidang kerja bagi penderita dengan HBsAg positif. Selain semua bayi, anak dan remaja yang tidak menerima vaksin pada masa bayi merupakan subyek yang membutuhkan vaksinasi. Juga orang dewasa, jika pasangannya pengidap Hepatitis B, memiliki partner seksual lebih dari satu, pengguna narkoba suntik, pekerjaan yang melibatkan darah manusia. Pasien-pasien hemodialisa dan tahanan dalam penjara juga membutuhkan vaksinasi Hepatitis B untuk mencegah tertularnya penyakit ini. (Kusnanto P, 2016)

\section{KESIMPULAN DAN SARAN Kesimpulan}

Dari hasil pemeriksaan anti-HBs diperoleh 20 anak (87\%) dengan serokonversi positif dan 3 anak (13\%) dengan serokonversi negatif.

Dari hasil pengenceran yang dilakukan pada serum dengan serokonversi positif, didapat hasil 4 sampel (20\%) negatif pada pengenceran $1: 2,3$ sampel (15\%) positif sampai pengenceran $1: 2$ saja, 5 sampel (25\%) positif sampai pada pengenceran 1:4, 4 sampel $(20 \%)$ positif pada pengenceran 1:6, 2 sampel (10\%) positif pada pengenceran 1:8 dan 2 sampel (10\%) tetap positif pada pengenceran 1:10.

\section{Saran}

\section{Bagi Masyarakat}

Meningkatkan kepedulian terhadap usaha peningkatan derajat kesehatan dan pencegahan penyakit, khususnya penyakit hepatitis B dengan melakukan vaksinasi sesuai anjuran kepada subyek-subyek dengan resiko tinggi.

\section{Bagi Pemangku Kebijakan di Layanan Kesehatan}

Meningkatkan kualitas layanan kesehatan dengan upaya-upaya preventif dan promotif sebagai ujung terdepan dalam usaha mengatasi permasalahan penyakit menular khususnya hepatitis B.

\section{DAFTAR PUSTAKA}

Anna LK. 2015. Imunisasi Hepatitis B Menunjukkan Hasil. (online)http://health.kompas.com/read/2015/08/31/15190 0023/Imunisasi.Hepatitis.B.Menunjukkan. Hasil, diakses 16 Januari 2017

Anonim. 2008. Viral Hepatitis. (online)_https://www.cdc.gov/ hepatitis/hbv/, diakses 16 Januari 2017

Anonim. 2015. W A S P A D A !! 2,9 Juta Lebih Penduduk Indonesia Mengidap Hepatitis (online), http://www.pusdatin.kemkes.go.id/article/view/15073000 001/w-a-s-p-a-d-a-2-9-juta-lebih-penduduk-indonesiamengidap-hepatitis.html, diakses 16 Januari 2017

Astuti HP, Kusumawati E. 2014. Kajian Efektivitas Pemberian Vaksinasi Hepatitis B Terhadap Pembentukan Antibodi Anti Hbs (online) http://download.portalgaruda.org/article. php?...Kajian \%20Efektivitas $\% 20$ Pemberian $\% 20$ Va..., diakses 16 Januari 2017

Dumolard L, Gacic-Dobo M, ShapiroCN, dkk. 2008. Implementation of Newborn Hepatitis B Vaccination. (online) https://www.cdc.gov/mmwr/preview/mmwrhtml/mm574 6a1.htm?s cid=mm5746a1 e, diakses 16 Januari 2017

Eric E., Margolis HS, Fiore AE. 2008. A Comprehensive Immunization Strategy to Eliminate Transmission of Hepatitis B Virus Infection in the United States (online) https://www.cdc.gov/mmwr/preview/mmwrhtml/rr5416a 1.htm?s cid=rr5416a1 e, diakses 16 Januari 2017

Jatmiko SW, Aisyah R. 2015. Imunitas Alamiah. Sebelas Maret University Press. Surakarta

Kosasih EN, Kosasih AS. 2008. Tafsiran Hasil Pemeriksaan Laboratorium Klinik Edisi Kedua. Karisma Publishing Group. Tangerang

Kresno SB. 2001. Imunologi : Diagnosis dan Prosedur Laboratorium. Gaya Baru. Jakarta

Kusnanto P. 2016. Perjalanan Penyakit dan Beban Psikologik Penderita Hepatitis B dan C. dalam Internal Medicine: Comprehensive Management of The Disease in Daily

Riswanto. 2013. Pemeriksaan Laboratorium Hematologi. Alfamedia dan Kanal Medika. Yogyakarta

Setyawan PB, Djumhana A, Akbar N dkk. 2006. Panduan Tata Laksana Hepatitis Kronik (online) http://pphi-online.org/

Sufa IG. 2013. Dua Puluh Lima Juta Penduduk Indonesia Terpapar Hepatitis (online) https://m.tempo.co/read/ news $/ 2013 / 09 / 08 / 060511386 / 25$-juta-pendudukindonesia-terpapar-hepatitis, diakses 16 Januari 2017 
Yugata HH. 2015. Hubungan Antara Usia dengan Titer AntiHBs pada Anak yang Telah Mendapatkan Imunisasi Hepatitis $B$ Lengkap. http://etd.repository. ugm.ac.id/index. php? mod=penelitian detail\&sub= $\underline{\text { PenelitianDetail\&act }=\text { view\&typ }=\mathrm{html} \& \text { buku } \mathrm{id}=79346}$ \&obyek id $=4$
Zain LH. 2006. Hepatitis dan Permasalahannya. (online) http://www.budilukmanto.org/index.php/seputarhepatitis/35-seputar-hepatitis/87-seputarhepatitis?tmpl $=$ component\&print $=1 \&$ page $=$, diakses 16 Januari 2017 